\title{
How Does Strong Experiential Marketing Affect the Customer Value?
}

\author{
Ananta Budhi Danurdara ${ }^{1}$, Nurdin Hidayah $^{2} \&$ Anwari Masatip $^{1}$ \\ ${ }^{1,}$ Hospitality Department, Bandung Institute of Tourism, Bandung, Indonesia \\ ${ }^{2}$ Tourism Department, Bandung Institute of Tourism, Bandung, Indonesia \\ Correspondence: Nurdin Hidayah, Tourism Department, Bandung Institute of Tourism, Bandung, Indonesia. Tel: \\ 62-22-20114546. E-mail: nurdin@stp-bandung.ac.id
}

\author{
Received: June 7, 2017 Accepted: July 11, 2017 Online Published: July 28, 2017 \\ doi:10.5539/ijms.v9n4p89 URL: http://doi.org/10.5539/ijms.v9n4p89
}

\begin{abstract}
The research objective is to get empirical evidences as well as to elucidate the phenomenon so that conclusion can be drawn concerning the implementation of Experiential Marketing in Creating Customer Value at stars' hotel of 3, 4 and 5 in West Java, Indonesia. This study uses quantitative approach and Structural Equation Modeling was conducted to test the hypothesis. To meet the adequacy of the data, it was decided to have sample of 210 respondents, consisting of hotel customers who were room occupants of 3,4 , and 5 star hotels in the West Java province. Collection of field data in order to obtain primary data was done through observation, deployment questionnaires, interviews and search and collecting documents. The results confirmed the importance of experiential marketing implementation since it can increase customer value, and it also has implications for customer loyalty.
\end{abstract}

Keywords: customer value, experiential marketing, structural equation modelling

\section{Introduction}

\subsection{Problem}

The tourism industry sector of Bandung city is significantly influential toward economic growth with a contribution to regional revenue of Bandung city in 2011, penetrating $40 \%$ of the total revenue (Kamalia Purbani, Head of Bappeda Bandung). Based on data from Dinas Pariwisata Daerah Jawa Barat (2013), there were 1,552 hotel and other accommodations that have been established in West Java. The number of rooms are as many as 43,981 hotel rooms and 72,105 beds. The increasing the number of hotels was due to a hospitality entrepreneur's business calculation that estimating the need for new hotels. Unfortunately, this high number of hotel was not accompanied by high occupancy rates (Danurdara \& Hidayah, 2016).

According to Doddy Gunawan Yusuf, Head of West Java Distribution Statistics (2014), the low occupancy rate is largely due to the intense competition in the hospitality industry. The fact that stars hotel rooms are unoccupied is caused by tourists are distributed to new hotels as well as other accommodation estabslishments as the result of increasing number of construction and operating permits of new hotels around Bandung city and West Bandung Regency. Yana Mulyana Supardjo, Chairman of the Council of Real Estate Indonesia (REI) in bandung.bisnis.com (2014) said, this is even getting worse by the presence of several apartments in Bandung whose room converted as hotel. Intense competition and the low occupancy rate of the hotel rooms makes the hotel companies need to think about the right strategy to increase the number of visits and the occupancy of hotel rooms (Danurdara \& Hidayah, 2016).

Based on the preliminary survey results concering 50 respondents in several hotels in the West Java province during June to August 2014 it is identified that that the hotel occupancy can not be separated from customers unique experience during the stay. In intense competition, the priority should be given to customer satisfaction, so that companies can survive, compete and dominate market share (Isnadi, 2010).

Factors such as the increasing number of competitors, technological sophistication and increased education about marketing accelerates and encourage marketers to be creative to market their products. Zikmund et al. (2009) cited Sanders, director of Yahoo, states that the experience is the basis of a new economy for all industries. Further Sanders stated that today is the time to experience economy. Regardless of the product or service being sold, a marketer needs to provide an unforgettable experience for customers because it is the one that is highly 
valued.

According to Groroos (2011), the success of a company's internal plan, especially related to strategic planning in the field of marketing and services there are 2 (two) devices, namely hardware and software. The next four elements are style, skills, staff, and shared values. All are the "software" is indispensable in providing excellent service experience for customers.

Kotler \& Amstrong (2010) states that a company needs to establish a accurate marketing and service strategy, because if not, companies will lose in the competition to grab market share. Customers will see the physical environment (physical evidence) as a guide to the quality of a company. Putri \& Astuti (2010) argues that the tangible aspects is the main attributes that influence the decision to stay at the hotel.

The research raises the issue of experiential marketing with a case study on star hotels of 3, 4 and 5 in the West Java province. The low occupancy rate of star hotels in the West Java province is possibly caused by inappropriate marketing strategy to meet the needs and desires of consumers and to be able to provide a unique experience for the consumer. Based on the above assumption it is necessary to do an in-depth study on the implementation of experiential marketing at star hotel that will also measure its effect in increasing hotel customer value, Wijaya (2014) states that sense marketing of experiential marketing can positive effect on customer value.

In relation with the above discussion this study focused to determine how much influence of experiential marketing to customer value hotel in the West Java Province.

This research was conducted only in star hotels of 3, 4, and in the West Java province. The reasons are , among others: supporting facilities hotels 3,4 , and 5 starr are relatively similar such as a restaurant, pool, and room facility has been standardized. In addition to that marketing programs and marketing efforts are done adequately and more freely in 3, 4 and 5 star hotels. Moreover, consumers prefer to stay in star hotels by reason of pride and privacy that consumers have when staying in 3, 4, and 5 star hotels.

Seeing the above reasons the writer feels it is necessary to do research on experiential marketing in realizing customer value, in 3, 4, and 5 star hotels in the West Java province, and the title formulae is as follow: How Does Strong Experiential Marketing Marketing Affect the Customer Value (A Survery of Customer Star Hotels of 3, 4, and 5 in West Java Province)

\subsection{Importance of the Problem}

Along with the identification and formulation of problems above the purpose of this study is to analyze and determine the influence of experiential marketing toward customer value in star hotels. The purpose of this study are expected to provide scientific theoretical contribution, especially in the development of economics and marketing management services using approaches and methods in order to explore and find new approaches in the implementation of marketing methods in the world the hospitality industry, especially in the concept:

a. Marketing experiential of the hotel, which is related to the utilization dimensions / indicators: sense, feel, think, act, and relate marketing.

b. Customer value of the hotel, which is related to the utilization dimensions / indicators:

- The total customers value includes all the value derived from the product (product value), the value of the service (service value), the sales personnel (personnel value), and the company's image (image value), as well as

- The total costs include the price paid (monetary price) by the customer, the cost of time (time cost), the cost of energy expenditure (energy cost), and the cost of psychological (psychic cost).

\subsection{Relevant Scholarship}

Engel in Karyani (2013, p. 208), stated that customer service does not get "something good" from the results of a service, but to get more services in the form of experience and not ownership. When associated with the services marketing performed by the hotel, the hotel service marketing strategy is focused on hotel management efforts to create an exchanges that allow the company to maintain viability for growth and profit.

Further more Kotler dan Armstrong (2010, p. 11) states that "The key to achieving objectives depends on determining the needs and wants of target markets, giving the desired satisfaction more effectively and more efficiently than the competitors". The marketing concept stems from the departure of well-defined market, focusing on customer needs, coordinating all marketing activities affecting customers and generate profits and create customer satisfaction.

Schmitt in Kusumawati (2011, p. 13) stated that experiential marketing concept is an approach that uses the 
whole experience of the senses, feelings / affective, cognitive, physical, and lifestyle, as well as the relationship with culture or a particular reference, which is ultimately capable of providing an imagination that will impact on the incidence of customer value at a products or services. Elements sense, feel, think, act, and relate guiding marketing, makes experiential marketing different from the traditional concept (Putri \& Astuti, 2010, p. 48).

Indriyani (2009, p. 18) in the research entitled Effect of Experiential Marketing Against Customer Value, concluded that between experiential marketing and customer value has a strong and positive relationship, where the greater the perceived of experiential marketing, the greater the value of the customer is able to formed. Thus it can be stated that the implementation of experiential marketing, which consists of elements of sense, feel, think, act, and relate marketing prior estimat and the terms of the theoretical will affect customer value.

\subsection{Hypotheses}

Based on the description of the background, the formulation of the problem, and thinking framework of the above the hypotheses of this study can be formulated as follows:

H1: experiential marketing influence toward customer value of stars' hotel.

\section{Method}

\subsection{Method Approach}

The method used in this research is survey method with descriptive approach to answer the research objectives concerning customer assessment of the application of marketing experiential concepts, customer relationship marketing and customer value at stars' hotel in the West Java province which is carried out through data collection in the field from the respondents with a certain number of samples. Specially to answer the purpose of research on the influence of experiential marketing and customer relationship marketing towards customer value in stars' hotel in the West Java province carried out using the verification method approach.

\subsection{Operationalization of Variables}

Variables to be analyzed in this study are:

Experiential marketing (EM): as an exogenous variable

Customers relationship marketing (CRM): as an exogenous variable

Customer Value (CV): as the endogenous variable (intervening / mediator)

Experiential marketing was adopted and modified using the terms and definitions based on Dauhan \& Kanaidi (2010) study, the dimensions of Experiental Marketing measurement are: (1) Sense; (2) Feel; (3) Think; (4) Act; (5) Relate.

Customer Relationship Marketing-CRM refers to "all marketing activities directed toward establishing, developing and maintaining succesfult relational exchange". Adopted and modified using the terms and definitions based on Kusmayadi (2010). In this study, the dimensions are Understanding Customer Expectations, Building Service Partnership, Total Quality Management, Empowering Employees.

Cusomer Value-CV is the difference between the prospective customer's evaluation of all the benefits and all the costs of an offering and the perceived alternatives. Was adopted and modified using the terms and definitions based on Kotler \& Armstrong. In this study, the dimensions are Benefit and Cost. 
Table 1. Operationalization of variables matrix

\begin{tabular}{|c|c|c|}
\hline Variables & Dimensions & Indicators \\
\hline \multirow{19}{*}{$\begin{array}{l}\text { Experiential Marketing } \\
\text { Providing experience to consumers via emotion } \\
\text { (Schmitt in Putri and Astuti, 2013, p. 193), }\end{array}$} & Sense (EM1) & Sight \\
\hline & & Sound \\
\hline & & Tough \\
\hline & & Smell \\
\hline & & Taste \\
\hline & Feel (EM3) & Feeling \\
\hline & & Emotion \\
\hline & & Mood \\
\hline & Think (EM3) & Convergent \\
\hline & & Divergent \\
\hline & & Surprise \\
\hline & & Intrique \\
\hline & & Provocation \\
\hline & Act $\left(\mathrm{EM}_{4}\right)$ & Interaction \\
\hline & & Action \\
\hline & & Lifestyle \\
\hline & Relate $\left(\mathrm{EM}_{5}\right)$ & Self-Idealization \\
\hline & & Others \\
\hline & & Culture \\
\hline \multirow{8}{*}{$\begin{array}{l}\text { Cusomer Value is the difference between the } \\
\text { prospective customer's evaluation of all the } \\
\text { benefits and all the cost of an offering and the } \\
\text { perceived alternative (Kotler, 2010, p. 133) }\end{array}$} & Benefit (CV1) & Product Value \\
\hline & & Service Value \\
\hline & & Personnel Value \\
\hline & & Image Value: \\
\hline & Cost $\left(\mathrm{CV}_{2}\right)$ & Monetary Cost \\
\hline & & Time Cost \\
\hline & & Energy Cost \\
\hline & & Psychic Cost \\
\hline
\end{tabular}

\subsection{Sampling Procedures}

The population in this study is the hotel customers / tourists that have used and who was a hotel room occupant of 3, 4, and 5 stars' hotel in West Java Province. Based on the data obtained from the results of a preliminary survey in July 2014 in several hotels in West Java province is known that hotel customers of 3, 4, and 5 stars' hotel for the year 2013 were as many as 74,905, with the composition as shown in the following table.

Table 2. Customer composition of 3, 4, dan 5 star hotels in West Java Province, year of 2013

\begin{tabular}{lclc}
\hline No & Hotel Classification & Number of Hotel & Number of Customers \\
\hline 1 & Star 3 & 38 & 37.453 \\
2 & Star 4 & 28 & 26.217 \\
3 & Star 5 & 11 & 11.236 \\
\hline Total & & $\mathbf{7 7}$ & $\mathbf{7 4 . 9 0 5}$ \\
\hline
\end{tabular}

Method of sampling in this study was calculated using Stratisfied Proposionalle Cluster Random Sampling. Dauhan \& Kanaidi (2010), stratified sampling is taking samples with regard to the strata (levels) and classes of the population.

To determine the sample size, the Slovin formula is used Cooper \& Schindler (2009). After the calculation using the above formula it was found minimal sample size $n=203.571$ or rounded to $=204$. To meet the adequacy of the data, it was decided to have sample of 210 respondents, consisting of hotel customers that have used and who was a hotel room occupants of 3, 4, and 5 star hotels in the West Java province with the number of respondents represented each classification of hotel. Collection of field data in order to obtain primary data was done through: observation, deployment questionnaires, interviews and search and collecting documents.

\subsection{Research Framework}

Below is a figure on the framework of this research. 


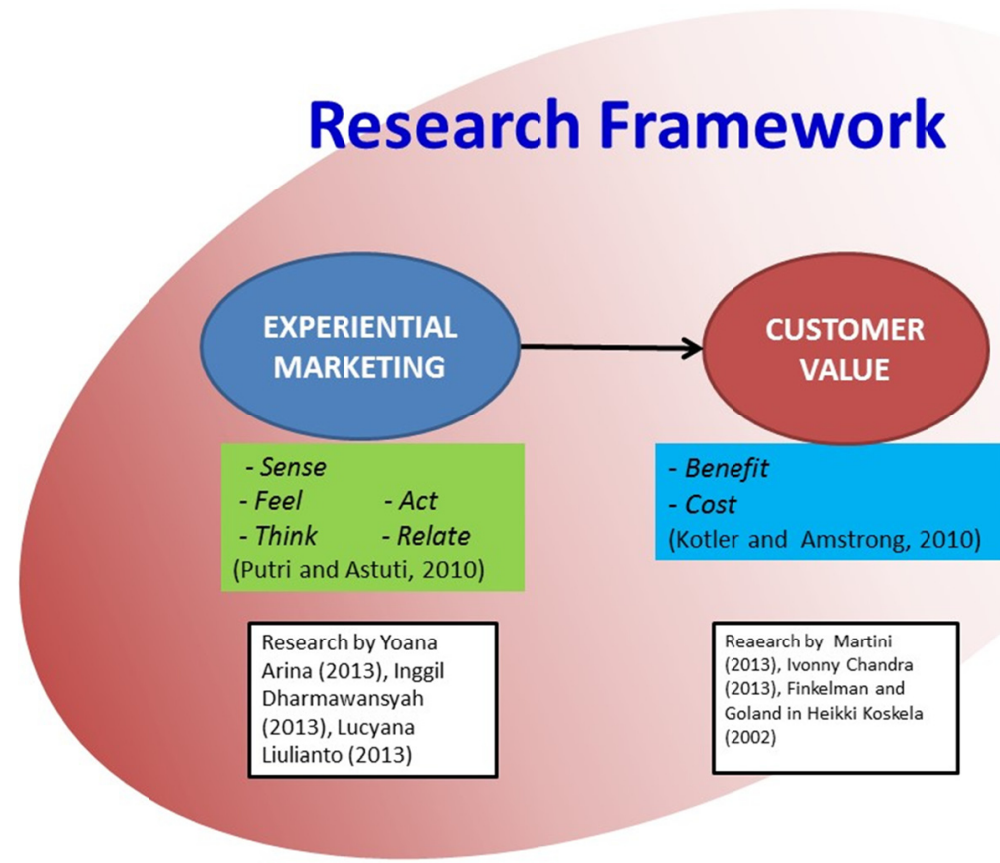

Figure 1. Research framework (influence among variables)

The paradigm of this research reflects the relationship between experiential marketing and customer relationship marketing to the customer. Where the dimensions of experiential marketing, which consists of sense, think, act, and feel relate simultaneously have an impact on customer value. The experience gained from the customer's physical and emotional stimuli shows the company's commitment in providing the best service for the customers so that the company can establish long-term relationships with customers.

Thus, not yet optimal experiental marketing efforts conducted by star hotels can lead to low customer value in this case is the dimension of cost and benefit. This is considering the services of hotel services is an activity directly related to the customer and at the same time is a barometer of the success of providing services provided. Personal experience, information received from others, and promotions by star hotels all have an impact on star hotel customers.

\section{Results}

\subsection{Analysis of Measurement Model Variable for Experiential Marketing}

The analysis used in SEM is to test the validity and reliability of each dimension forming experiential marketing variables, dimensions considered valid if it has a weighting factor of greater than 0.50 .

Based on the processed data using LISREL 8.7 software, the test results of each dimension on related variables using confirmatory factor analysis, were presented in the following table.

Table 3. Summary of confirmatory factor analysis, measurement model variable experiential marketing

\begin{tabular}{llllll}
\hline Dimensions & Loading Factors & $\mathbf{R}^{2}$ & Error variance & CR & VE \\
\hline Sense $\left(\mathbf{E M}_{1}\right)$ & 0,785 & 0,616 & 0,384 & & \\
Feel $\left(\mathbf{E M}_{2}\right)$ & 0,948 & 0,899 & 0,101 & & \\
Think $\left(\mathbf{E M}_{3}\right)$ & 0,896 & 0,803 & 0,197 & 0,945 & 0,774 \\
Act $\left(\mathbf{E M}_{4}\right)$ & 0,880 & 0,774 & 0,226 & & \\
Relate $\left(\mathbf{E M}_{5}\right)$ & 0,882 & 0,778 & 0,222 & & \\
\hline
\end{tabular}

Source: Data Processing Results.

Based on the results of the confirmatory factor analysis can be seen the value of each dimension weighting factor greater than 0.50 . This means that all dimensions are valid in shaping experiential marketing variables. Value construct reliability (CR) of 0.945 is greater than 0.70 which indicates that the five dimensions have consistency 
in measuring experiential marketing. Furthermore, the variance extracted (VE) of 0.774 indicates that on average 77.4 percent of the information contained in each dimension may be reflected through experiential marketing variables.

\subsection{Variable Value Measurement Model Analysis of the Customer Value}

Table 4. Summary of confirmatory factor analysis model customer value measurement variable

\begin{tabular}{llllll}
\hline Dimension & Loading Faktor & $\mathbf{R}^{2}$ & Error variance & $\mathbf{C R}$ & VE \\
\hline Benefit $\left(\mathbf{C V}_{\mathbf{1}}\right)$ & 0,811 & 0,658 & 0,342 & 0,811 & 0,683 \\
Cost $\left(\mathbf{C V}_{\mathbf{2}}\right)$ & 0,841 & 0,707 & 0,293 & & \\
\hline
\end{tabular}

Source: Data Processing Results.

Based on the results of the confirmatory factor analysis can be seen the value of each dimension weighting factor greater than 0.50 . That is valid both dimensions in forming variable customer value. Value construct reliability (CR) of 0.811 is greater than 0.70 indicate that both dimensions have consistency in measuring customer value. Furthermore, the variance extracted (VE) of 0.683 indicates that on average 68.3 percent of the information contained in each dimension may be reflected through the variable customer value.

\section{Discussion}

Structural model 1st reflects the relationship between experiential marketing to the customer, which is expressed in the following hypothesis: experiential marketing that significantly affect the customer value either partially or simultaneously. Based on the data processing program LISREL for structural model 1st, in accordance with the proposed hypothesis is as follows:

$\mathrm{CV}=0.388 * \mathrm{EM}$

\subsection{8}

Based on the above equation can be explained that:

There is a variable degree of contribution of experiential marketing to customers value the magnitude of 0.388 . So the better the experiential marketing undertaken by the hotel, it will contribute to customer value amounted to 0,388 .

Structural model $1^{\text {st }}$ reflects the relationship between experiential marketing to the customer value, which is expressed in the following hypothesis: experiential marketing that significantly affect customer value either partially or simultaneously. Based on the results of data processing LISREL program, in accordance with the proposed hypothesis is as follows:

$\mathrm{CV}=0.388^{*} \mathrm{EM}, \mathrm{R}^{2}=0.612$

Based on the above equation can be explained that: There is a variable degree of contribution of experiential marketing to customer value the magnitude of 0.388 . So the better of the experiental marketing undertaken by the hotel, it will contribute to customer value amounted to 0,388 .

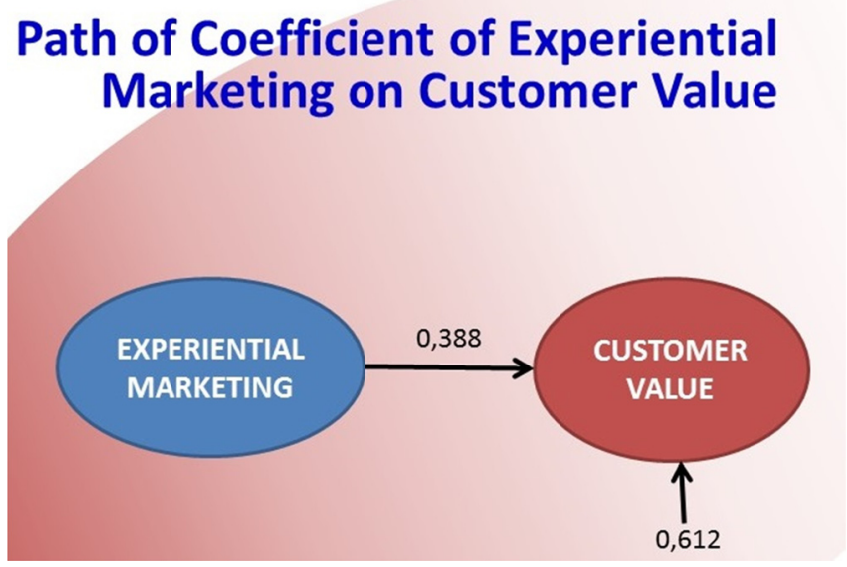

Figure 2. Path coefficient 
The results of processing the data also showed the value of R2 to the above equation is equal to 0.612 , this portrait that customer value is affected simultaneously by experiential marketing. This value also indicates that there are still other factors that affect the value of customers outside factors experiential marketing addressed by the error variance, amounting to 0.612 .

Based on correlation and path coefficient value obtained from the calculation with lisrel 8.5 can be known that the magnitude of the direct influence of experiential marketing.

The magnitude of these effects is caused by:

1). Indicator $\mathrm{X} 4$ (ability of sense of smell), the most powerful in reflecting the dimension (EM1) of experiential marketing that also affects the value of the customer.

2). Indicators $X 6$ (Feeling with specific stimulation), the most powerful in reflecting the dimension (EM2) of experiential marketing that also affects the value of the customer.

3). Indicators $X 8$ (mood), which is also strong in reflecting the dimension (EM2) of experiential marketing that also affects the value of the customer.

4). Indicators X12 (Admiration that exceeds that of surprise), the most powerful in reflecting the dimension (EM3) of experiential marketing that also affects the value of customers, the hotel West Java Province was able to make a surprise to customers by delivering something in excess of what was promised.

5). Indicators X10 (freedom of thought simultaneously), which is also strong in reflecting the dimension (EM3) of experiential marketing that also affects the value of the customer.

6). Indicators X14 (Strong interaction), which is also strong in reflecting the dimension (EM4) of experiential marketing that also affects the value of the customer.

7). Indicators X17 (idealization of a person to a product), which is also strong in reflecting the dimension (EM5) of experiential marketing that also affects the value of the customer.

The direct effect of experiential marketing variables on customer value amounted to $15.03 \%$. This indicates that experiential marketing adopted by the company has been relatively good.

\section{References}

Chandra, I. (2013). Analisa Pengaruh Experiential Marketing Terhadap Customer Satisfaction Dengan Perceived Value Sebagai Variabel Intervening Konsumen The Premiere Grand City Surabaya. Jurnal Manajemen Pemasaran Petra, 1(2), 1-10.

Cooper, D. R., \& Schindler, P. S. (2009). Business Research Methods (11th ed.). New York: McGraw Hill.

Danurdara, A. B., \& Hidayah, N. (2016). Service Quality As A Competent Marketing Strategy to Maintain Customer Loyalty: A Case Study in Three Star Hotel. VSRD International Journal of Business and Management Research, 4(4), 107-114.

Dauhan \& Kanaidi. (2010). Pengaruh Kualitas Jasa, Nilai Jasa, Dan Kepuasan Pelanggan Terhadap Perilaku Minat Pembelian Konsumen Pos Ekspres Di PT Pos Indonesia Wilayah Bandung Raya, ProMaRK. Jurnal Bisnis dan Pemasaran Politeknik Pos Indonesia, 2(1), 62.

Dharmawansyah, I. (2013). Pengaruh Experiential Marketing Dan Kepuasan Pelanggan Terhadap Loyalitas Pelanggan (Studi Kasus Pada Rumah Makan Pring Asri Bumiayu). Management Anaysis Journal, 2(2), $1-10$.

Grönroos, C. (2011). A Service Perspective on Business Relationships: The Value Creation, Interaction and Marketing Interface. ELSEVIER, Industrial Marketing Management Journal, 40(2011), 240-247. https://doi.org/10.1016/j.indmarman.2010.06.036

http://diskominfo.jabarprov.go.id

http://disparbud.jabarprov.go.id

http://phri-jabar.or.id

http://www.parekraf.go.id

Indriyani, F. (2009). Experiential Marketing Sebagai Suatu Strategi Dalam Menciptakan Customer Satisfaction Dan Repeat Buying Untuk Meningkatkan Kineria Pemasaran. Jurnal Studi Manajemen \& Organisasi, 3(1), 28-39.

Isnadi. (2010). Analisis Pengaruh Customer Relationship Marketing Terhadap Nilai Pelanggan dan Keunggulan 
Produk Dalam Meningkatkan Kepuasan dan Loyalitas Pelanggan. Program Pasca Sarjana Universitas Diponegoro, Semarang.

Karyani. (2011). Keluarga Sebagai Ranah Utama Kesejahteraan Siswa. Jurnal Ilmiah PARENTING, 3(1), 206-213.

Koskela, H. (2002). Customer Satisfaction and Loyalty in After Sales Service: Modes of Care in Telecommunications Systems Delivery. HUT Industrial Management Work and Organizational Psychology. Report No 21.

Kotler \& Armstrong. (2010). Prinsip-prinsip Pemasaran Jilid 1. Jakarta: Erlangga.

Kusmayadi, T. (2010). Pengaruh Relationship Quality terhadap loyalitas nasabah Bank BNI. STIE STAN Indonesia Mandiri, Jurnal Bisnis \& Akutansi, 1-19.

Kusumawati, A. (2011). Analisis Pengaruh Experiential Marketing Terhadap Kepuasan Dan Loyalitas Pelanggan: Kasus Hypermart Malang Town Square (MATOS). Jurnal Manajemen Pemasaran Modern, 3(1), 80.

Liulianto, L. (2013). Pengaruh Experiential Marketing dan Experiential Value Terhadap Customer Satisfaction Samsung Galaxy (GT N7000) di Surabaya, CALYPTRA. Jurnal Ilmiah Mahasiswa Universitas Surabaya, 2(2), 1-19.

Martini, L. K. B. (2013). Relationship Marketing, Customer Satisfaction dan Customer Loyalty Bank Nasional di Denpasar. Buletin Studi Ekonomi, 18(1), 1-84.

Pramudita, Y. A. (2013). Analisa Pengaruh Customer Value dan Customer Experience terhadap Customer Satisfaction di De Kasteel Resto Surabaya. Jurnal Strategi Pemasaran, 1(1), 1-7.

Putri, A. Y., \& Astuti, T. S. R. (2010). Analisis Pengaruh Experiential Marketing terhadap Loyalitas Pelanggan Hotel "X" Semarang. Aset, 12(2), 191-195.

Wijaya, A. (2014). Analisis Pengaruh Experiential Marketing Terhadap Repeat Purchase Dengan Customer Satisfaction Sebagai Mediating Variable Di De Mandailing Cafe UC Boulevard Surabaya. Jurnal Strategi Pemasaran, 2(1), 1-9.

Zikmund, W. G., McLeod, R. Jr., \& Gilbert. (2009). Customer Relationship, Management, Integrating Marketing Strategy and Information Technology (International Edition). New York: Wiley.

\section{Copyrights}

Copyright for this article is retained by the author, with first publication rights granted to the journal.

This is an open-access article distributed under the terms and conditions of the Creative Commons Attribution license (http://creativecommons.org/licenses/by/4.0/). 